\title{
Reaction of maize hybrids to Northern corn leaf blight and common rust, and chemical control of Northern corn leaf blight
}

\section{Reação de híbridos de milho a helmintosporiose e ferrugem comum, e controle químico de helmintosporiose}

\author{
Juliane Nicolodi Camera ${ }^{1 *}$ (D), Carlos Alberto Forcelini ${ }^{2}$ (D), Jana Koefender ${ }^{1}$ (D), \\ Diego Pascoal Golle ${ }^{1}$ (D), André Schoffel ${ }^{3}$ (D), Carolina Cardoso Deuner ${ }^{2}$ (D)
}

\begin{abstract}
Northern corn leaf blight (NCLB) and common rust are among the primary fungal diseases affecting maize production. This study aimed to evaluate the susceptibility of ten maize hybrids to NCLB and to common rust and to verify the efficiency of fungicides in the chemical control of Exserohilum turcicum. In the first experiment, hybrids Pioneer (30F53, P1630H, P2530), Monsanto (AG 8045, AG 9045), Dow AgroSciences (2A550, 2A106 and 2B587) and Syngenta (SYN7205 VIPTERA, SW 3949 TL) were used and in the experiment for effectiveness of fungicides in the control of NCLB. The efficiency of fungicides propiconazole, azoxystrobin, cyproconazole + azoxystrobin, prothioconazole + trifloxystrobin, benzovindiflupir + azoxystrobin, cyproconazole + azoxystrobin + mancozeb were tested in the Pioneer $\mathrm{P} 1630 \mathrm{H}$ hybrid. In both experiments, the leaf disease severity (\%), yield and the weight of one thousand seeds were evaluated. The experimental design was carried out in randomized blocks with four replicates. The hybrids SYN7205, P2530, SW 3949 TL, 2B587, AG 9045 , 2A550, P1630H, 2A106 and AG 8025 showed the smallest areas under the common rust severity progress curve. Hybrids AG9045, $30 F 53$, and 2A550 presented the smallest areas under the NCLB progress curve. Hybrids AG8025, 2B587, P1630H, AG9045, 2A106, 2A550, present the highest yields. The fungicides prothioconazole + trifloxystrobin present the highest chemical control efficiency for NCLB and the lowest area under the disease progress curve (AUDPC).
\end{abstract}

KEYWORDS: Puccinia sorghi; Exerohilum turcicum; fungicides; yield.
RESUMO: A helmintosporiose e a ferrugem comum estão entre as principais doenças fúngicas que afetam a produção do milho. Os objetivos desse trabalho foram avaliar a suscetibilidade de dez híbridos de milho a helmintosporiose e a ferrugem comum e verificar a eficiência de fungicidas no controle de Exserohilum turcicum. No primeiro experimento utilizaram-se os híbridos Pioneer (30F53, P1630H, P2530), Monsanto (AG 8045, AG 9045), Dow AgroSciences (2A550, 2A106 e 2B587) e Syngenta (SYN7205 VIPTERA, SW 3949 TL), e no experimento de eficiência de fungicidas no controle de helmintosporiose, testou-se a eficiência dos fungicidas propiconazol, azoxistrobina, ciproconazol + azoxistrobina, protioconazol + trifloxistrobina, benzovindiflupir + azoxistrobina, ciproconazol + azoxistrobina + mancozebe, no híbrido Pioneer P1630H. Em ambos os experimentos avaliaram-se a severidade foliar das doenças (\%), o rendimento e o peso de mil sementes. $\mathrm{O}$ delineamento experimental foi em blocos ao acaso com quatro repetições. Os híbridos SYN7205, P2530, SW 3949 TL, 2B587, AG 9045, 2A550, P1630H, 2A106 e AG 8025 apresentam as menores áreas abaixo da curva de progresso de severidade de ferrugem comum. Os híbridos AG9045, 30F53 e 2A550 apresentam as menores áreas abaixo da curva de progresso de helmintosporiose. Os híbridos AG8025, 2B587, P1630H, AG9045, 2A106 e 2A550 apresentam os maiores rendimentos. Os fungicidas protioconazol + trifloxistrobina apresentam a maior eficiência de controle químico de helmintosporiose e a menor AACPD.

PALAVRAS-CHAVE: Puccinia sorghi; Exerohilum turcicum; fungicidas; rendimento.

\footnotetext{
'Universidade de Cruz Alta - Cruz Alta (RS), Brazil

'Universidade de Passo Fundo - Passo Fundo (RS), Brazil

${ }^{3}$ Universidade Federal de Santa Maria - Santa Maria (RS), Brazil

*Corresponding author: ju_camera@yahoo.com.br

Received on: 01/19/2018. Accepted on: 06/05/2019
} 


\section{INTRODUCTION}

Maize crops are of great importance for the Brazilian economy, ranking as the second crop type with the largest grain production in the national territory, and with a large share of exports. Brazil is the third largest maize producer in the world (USDA, 2015), with most of its production concentrated in the second harvest (CONAB, 2016), known as safrinha.

Among the many causes that affect maize yield, we can mention fungal diseases as one of the main factors responsible for damages in productivity. There is a large number of fungi species that affect maize, but only a few cause significant losses. The distribution of these fungi in Brazil varies according to the region and to the growing period. Higher and cooler areas favor some diseases, while lower and warm regions benefit other fungi groups (COSTA; COTA, 2009). Some diseases have already been found causing damage to maize crops, including common rust (Puccinia sorghi Schw.) and Northern corn leaf blight (NCLB) (Exserohilum turcicum Pass.) (K. J. Leonard \& E. G. Suggs).

NCLB is a common disease in maize and displays a high economic impact. The damage caused depends on the severity and on the crop's stage of development at the time of infection, occurring mainly under conditions that are favorable to the development of the fungus, which are provided by humidity and temperature between 18 and $27^{\circ} \mathrm{C}$. If the cultivar does not have a satisfactory resistance level, the economic damage can be even more significant. Severe incidence before flowering causes great damage (KIMATI et al., 2005).

Common rust is a disease that can cause huge losses to the producer. Among the main control measures is the use of resistant cultivars, the elimination of host plants and avoiding plantations in unfavorable seasons when climatic conditions are highly favorable to the development of the disease (BALMER; PEREIRA, 1987).

The importance of the cultivated plants' resistance in the control of their diseases was recognized in beginning of the $20^{\text {th }}$ century, with the advances of genetics and phytopathology, which provided plant breeding with conditions for the growing of varieties that are resistant to the diseases, which are able to avoid the damage caused by the pathogens, simply by replacing the susceptible varieties with the resistant ones. Thus, the primary objective of most breeding programs has been the creation of resistant strains, being the most effective and economical method of controlling diseases, especially if combined with resistance to agronomic parameters of economic importance (PEREIRA et al., 1985). Maze hybrids with information on disease resistance are few, which is key for the selection of the hybrid to be used by rural producers.

The chemical control of leaf spot in maize crops has shown good results in control and yield maintenance when applied at the correct time (LAGO; NUNES, 2008). The results are usually seen as yield increase in comparison to non-pulverized areas (PINTO, 2004). The use of fungicides such as triazoles and strobilurins has been important for the management of diseases in susceptible maze hybrids (DUARTE et al., 2009). In addition, mixing these fungicides may increase the protection and the spectrum of action on pathogenic fungi.

As a result, this study aimed to verify the susceptibility of ten maze hybrids to helmintosporiosis and common rust and to verify the efficiency of fungicides in the chemical control of E. turcicum.

\section{MATERIAL AND METHODS}

The experiments were conducted in the Experimental Area of the Faculdade de Agronomia e Medicina Veterinária at Universidade de Passo Fundo, Passo Fundo, state of Rio Grande do Sul.

\section{Experiment 1: maze hybrids' reaction and leaf diseases}

The experiment was conducted in two crops: 2012/13 and 2013/14. The experiments were implemented under no-tillage system in an area cropped with maze in the previous year. Ten hybrids were seeded: Pioneer (30F53, P1630H, P2530), Monsanto (AG 8045, AG 9045), Dow AgroSciences (2A550, 2A106 and 2B587) and Syngenta (SYN7205 VIPTERA, SW 3949 TL). Those hybrids were selected because they are the most cultivated by the farmers in the region.

Sowing was carried out on November 13, 2012, using four rows per hybrid spaced at $0.45 \mathrm{~cm}$ with sowing density of 73,000 plants/ha. Foundation fertilization was $250 \mathrm{~kg} / \mathrm{ha}$ of $\mathrm{N}-\mathrm{P}_{2} \mathrm{O}_{5}-\mathrm{K}_{2} \mathrm{O}, 5-20-20$ fertilizer and $200 \mathrm{~kg} / \mathrm{ha}$ of urea $(45.5 \%$ of $\mathrm{N}$ ) split in two applications, the first one at the vegetative stage $\mathrm{V} 4(100 \mathrm{~kg} / \mathrm{ha})$ and the second at the vegetative stage V7 (seven fully developed leaves) $(100 \mathrm{~kg} / \mathrm{ha})$. The insecticide Lorsban $^{\circledR} 480$ (chlorpyrifos) was applied at $0.6 \mathrm{~L} /$ ha for the control of Spodoptera frugiperda (J.E. Smith). For weed control, Callisto $0.3 \mathrm{~L} / \mathrm{ha}+$ Primóleo $5 \mathrm{~L} /$ ha was used. The severity of NCLB and common rust in the first year was evaluated, and only the severity of NCLB was evaluated in the second year. The experimental design was a randomized block with four replicates and the data obtained were submitted to analysis of variance and compared by the comparison of means test using the Scott-Knott test at 5\%.

To measure the estimated Severity rating (\%) three plants from the second sowing row of each hybrid were collected in each of the replicates. These plants were collected in the field at $17,28,42,58$ and 78 days after emergence and were taken to the laboratory for evaluation, being given severity scores from 0 to $100 \%$ for NCLB and common rust, but only NCLB was evaluated in the second harvest. From the severity values, the area under the disease progress curve (AUDPC) was 
calculated according to RIBEIRO DO VALE et al. (2004), where this area represents the total amount of disease occurring during the crop cycle, using the formula: $\mathrm{AUDPC}=\Sigma$ $\{[(\mathrm{St}+\mathrm{St}-1) / 2] \times \Delta \mathrm{t}\}$ where $\mathrm{St}$ is the disease intensity at time $\mathrm{t}, \mathrm{St}-1$ is the disease intensity at time $\mathrm{t}-1$ and $\Delta \mathrm{t}$ is the time interval, in days, between evaluations.

By means of the severity data, the hybrids were also compared in relation to the evolution of the epidemic using the logistic model, and severity values were transformed into proportion (severity\%/100).

Yield ( $\mathrm{kg} / \mathrm{ha}$ ) was determined at the end of the crop cycle, when the ears of the third sowing row with $10 \mathrm{~m}$ in length were harvested manually to determine yield from weighing the grains obtained in the plot area, as well as moisture through a moisture meter. The data were transformed in $\mathrm{kg} / \mathrm{ha}$, followed by correction of the standard moisture to $13 \%$ using the formula $\mathrm{P} 13 \%=(\mathrm{GY}(100-\mathrm{M})) / 87 \%$, in which $\mathrm{P} 13 \%$ is the grain yield $(\mathrm{kg} / \mathrm{ha})$ corrected for the standard moisture of $13 \%$; GY grain yield without correction and $\mathrm{M}$ is the grain moisture observed at weighing.

The weight of one thousand seeds (WTS) was obtained by weighing 400 pure seeds, counted manually and separated by tray.

\section{Experiment 2: chemical control of Exserohilum turcicum}

The experiment was conducted in the 2013/14 crop. It was implemented under no-tillage system in an area cropped with soybeans in the previous year using the Pioneer P1630H hybrid since it was one of the most susceptible to NCLB. Sowing was carried out on November 14, 2013, with four rows per hybrid spaced at $0.45 \mathrm{~cm}$ with sowing density of 73,000 plants/ha. Crop management was similar to experiment 1.

This study evaluated six different fungicides (Table 1), applied in the pre-tasseling stage (RITCHIE et al., 1993), as well as an application of the fungicide cyproconazole +

Table 1. Fungicides used in the $2013 / 14$ crop and their respective doses. Passo Fundo, Rio Grande do Sul, 2015.

\begin{tabular}{|c|c|c|}
\hline Active ingredient & $\begin{array}{c}\text { Dose }^{2} \\
\text { (g a.i. /ha) }\end{array}$ & $\begin{array}{l}\text { Dose }^{3} \\
\text { (c.p. /ha) }\end{array}$ \\
\hline Propiconazole & 100 & $0.4 \mathrm{~L}$ \\
\hline Azoxystrobin & 75 & $0.3 \mathrm{~L}$ \\
\hline $\begin{array}{l}\text { Cyproconazole + } \\
\text { azoxystrobin }^{1}\end{array}$ & $24+60$ & $0.3 \mathrm{~L}$ \\
\hline $\begin{array}{l}\text { Prothioconazole + } \\
\text { trifloxistrobina }{ }^{2}\end{array}$ & $70+60$ & $0.4 \mathrm{~L}$ \\
\hline $\begin{array}{l}\text { Benzovindiflupir + } \\
\text { azoxystrobin } 1\end{array}$ & $30+60$ & $0.2 \mathrm{~kg}$ \\
\hline $\begin{array}{l}\text { Cyproconazole }+ \\
\text { azoxystrobin }{ }^{1}+\text { mancozeb }\end{array}$ & $\begin{array}{c}24+60+ \\
1500\end{array}$ & $0.3 \mathrm{~L}+2 \mathrm{~kg}$ \\
\hline
\end{tabular}

'Added Nimbus 600 mL/ha; ${ }^{2}$ Added Aureo 0.25\%; ${ }^{3}$ Active ingredient. azoxystrobin based on the Economic Injury Level (EIL) for the control of NCLB. Applications were carried out using a volume of $150 \mathrm{~L} / \mathrm{ha}$, with a backpack spray, $\mathrm{CO}_{2}$ pressurized, 3-m wide bar and TT 110015 flat jet spray tips.

The application in the EIL was calculated using the formula $\mathrm{ID}=\left(\mathrm{Cc} / \mathrm{Pp}{ }^{*} \mathrm{Cd}\right)^{*} \mathrm{Ec}$, where: $\mathrm{Cc}$ (control cost), $\mathrm{Pp}$ (ton price), $\mathrm{Cd}$ (damage coefficient), Ec (control efficiency). For example, $\mathrm{Cc}=\mathrm{R} \$ 100.00 / \mathrm{ha}, \mathrm{Pp}=388.33 /$ ton, $\mathrm{Ec}=60 \%$ and one of the obtained equations, $\mathrm{R}=1,000-27.4 \mathrm{I}$, where $\mathrm{l}=$ number of NCLB lesions in the spike leaf (estimating a yield of $9,000 \mathrm{~kg} / \mathrm{ha}$, the result is $\mathrm{Cd}=0.2466$ ). By replacing the values into the formula, the outcome was an EIL of 0.62 lesions in the spike leaf, indicating this value for the start of spraying (REIS et al., 2004). Fungicide (cyproconazole + azoxystrobin) at a dose of $0.3 \mathrm{~L} /$ ha was applied 23 days after the application of the other fungicides.

The AUDPC yield ( $\mathrm{kg} / \mathrm{ha}$ ) and weight of one thousand seeds were calculated in the same manner as in the previous experiment.

\section{RESULTS AND DISCUSSION}

\section{Experiment 1: maize hybrids' response to leaf diseases}

A different behavior between hybrids regarding the evolution of common rust (Fig. 1) and NCLB (Fig. 2) was observed in the 2012/13 crop. The evolution of common rust by the logistic model represented the evolution of the epidemic in hybrids SYN7205, SW 3949 TL, 2B587, 2A106 and AG 8025 , with a $5 \%$ significance level. For the hybrids 30F53, P2530, 2A550, AG 9045 and P1630H, the model was not significant (Table 2), since the severity values were less than $50 \%$, and the logistic model better represents epidemics that present values close to $50 \%$ of the evaluated variable, and perfect representation is not possible when the values are too high or too low. For NCLB, the hybrids SW 3949 TL, AG 8025, SYN7205, P2530, 2B587 and 2A550 had a 5\% significance level, and for the hybrids P1630H, 2A106, 30F53 and AG 9045, they were not significant, being the best representation for this disease due to severity values closer to $50 \%$ (Table 2).

From the hybrids' disease severity values, the AUDPC for common rust and NCLB was calculated for the 2012/13 harvests. For the first, it was found that the hybrid $30 \mathrm{~F} 53$ presented the highest value of this variable, differing statistically from the other hybrids, which did not differ among themselves. For NCLB, the hybrid $\mathrm{P} 1630 \mathrm{H}$ presented the highest value, differing statistically from the other hybrids (Fig. 3A).

In the 2013/14 crop, NCLB was the predominant disease. For the AUDPC, it was verified that the hybrids $\mathrm{P} 1630 \mathrm{H}$ and 2A106 were statistically superior to the other treatments, presenting the highest values of this variable (Fig. 3B). 

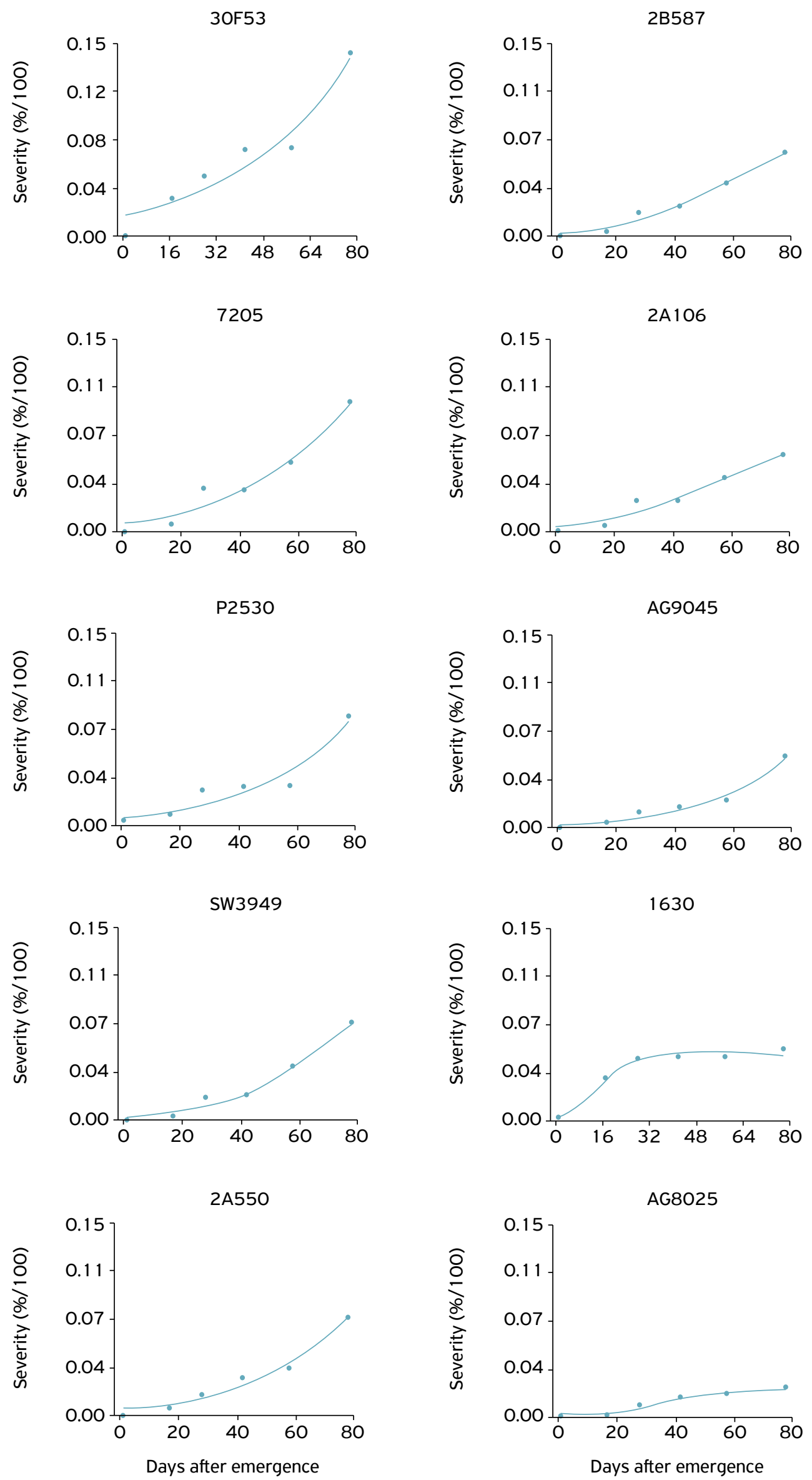

Figure 1. Evolution of common rust in different maize hybrids in 2012/13 crop. Passo Fundo, Rio Grande do Sul, 2015. 

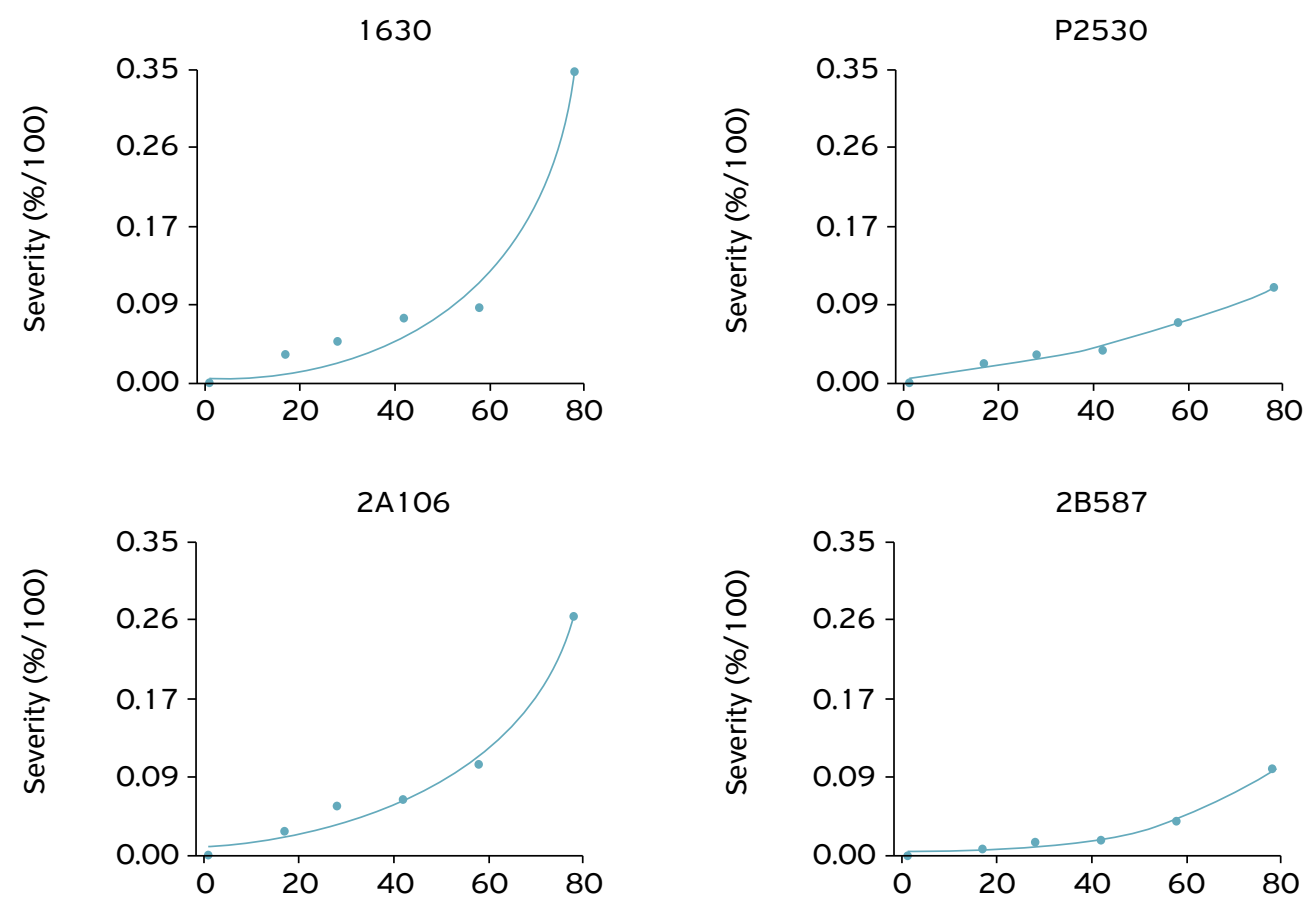

SW3949
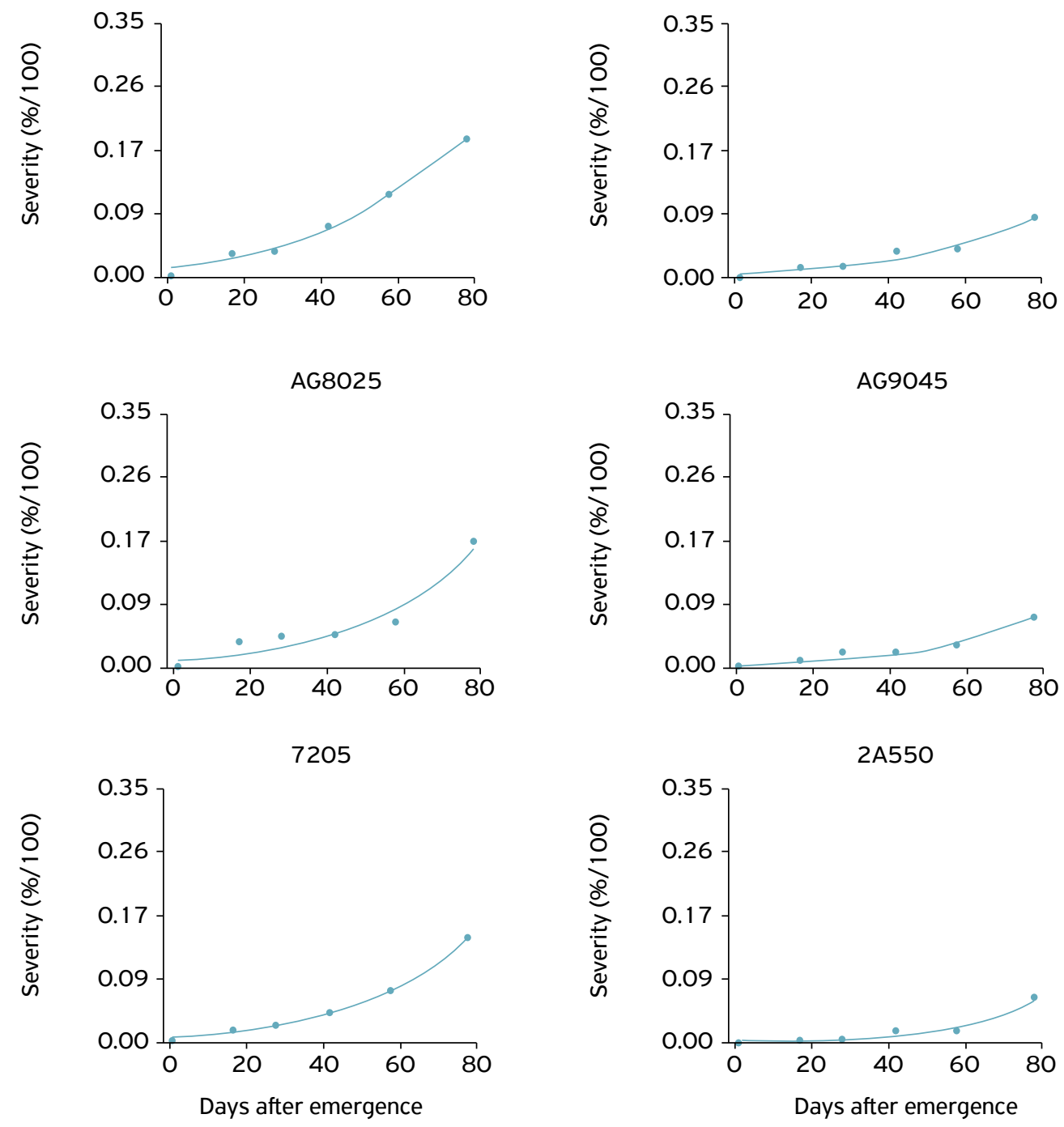

Figure 2. Evolution of Northern corn leaf blight in different maize hybrids in 2012/13 crop. Passo Fundo, Rio Grande do Sul, 2015. 
In the 2012/13 crop, the highest yields were verified for hybrids AG8025, 2B587, P1630H, AG9045, 2A106, SYN7205, 2A550, P2530. For the 2013/2014 crop, the highest yields were verified for the hybrids 2B587, 2A106, AG9045, 2A550, AG8025, P1630H and the lowest yields were obtained in the SYN7205 and P2530 hybrids, due to the lodging in the plants of hybrid SYN7250. Some hybrids presented lower yields in the 2013/14 crop, due to the long drought period at pollination (Table 3 ).

Regarding the WTS, in the 2012/13 crop, the highest values were verified for the hybrids AG9045, AG8025, P2530 and 2A550, which did not differ statistically among them, but were superior to all the others. The lowest values of this variable were verified for hybrids 2B587 and SW 3949 TL. In the 2013/14 crop, the hybrids AG9045, P1630H, AG8025, 30F53 and P2530 were statistically superior to the others (Table 3).

Maize crop yield depends on several factors, among which are climatic conditions, soil fertility, plant spacing and population, type of hybrid used and susceptibility to diseases. Studies on the susceptibility of hybrids to diseases like common rust and NCLB are still scarce the in the literature.
Several factors are linked to the increase in the incidence of pathogens in maize crops. Some of them are the emergence of more productive hybrids with different disease resistance levels, inadequate use of products and cropping systems, where crop rotations are not performed (WEBER, 2010). According to the diagrammatic scale by AGROCERES (1996), the average severity percentage, about 30 days after flowering, indicates the type of response of the different hybrid cultivars regarding resistance to E. turcicum.

The most efficient control measure for E. turcicum in maize is the use of genetic resistance, which may be vertical or monogenic and horizontal or polygenic resistance (CAMPAÑA; PATAKY, 2005). Monogenic resistance is conferred by four $\mathrm{Ht}$ genes ( $\mathrm{Ht} 1, \mathrm{Ht} 2, \mathrm{Ht} 3$ and $\mathrm{HtN}$ ). The expression of the resistance conferred by the $\mathrm{Ht} 1, \mathrm{Ht} 2$ and $\mathrm{Ht} 3$ genes results in chlorotic lesions with little pathogen sporulation. The $\mathrm{HtN}$ gene causes an increase in the incubation period and delay the onset of expression of the disease symptoms. The expression of horizontal resistance results in fewer lesions in resistant plants, increase in the incubation and latent period, reduction in production of conidia and reduction in the rate of

Table 2. Equation according to the logistic model of the evolution of common rust and Northern corn leaf blight in ten maize hybrids. Passo Fundo, Rio Grande do Sul, 2015.

\begin{tabular}{|c|c|c|}
\hline \multicolumn{3}{|c|}{ Common rust } \\
\hline Hybrids & Equation & p \\
\hline $30 F 53$ & $y=1.51 /\left(1+85.53^{*} \exp \left(-0.03^{*} t\right)\right.$ & 0.30 \\
\hline SYN7205 & $y=38820.6 /\left(1+4570820.28^{*} \exp \left(-0.03^{\star} t\right)\right)$ & $0.01^{*}$ \\
\hline P2530 & $y=29487.08 /\left(1+4578651.9^{*} \exp \left(-0.03^{*} t\right)\right)$ & 0.30 \\
\hline SW3949 TL & $y=21458.72 /(1+4584220.49 * \exp (-0.04 * t))$ & $0.02^{*}$ \\
\hline 2A550 & $y=25912.01 /(1+4580156.01 * \exp (-0.03 * t))$ & 0.06 \\
\hline 2B587 & $y=26358.72 /\left(1+4574908.64^{*} \exp \left(-0.03^{*} t\right)\right)$ & $0.04^{*}$ \\
\hline $2 A 106$ & $y=33571.5 /\left(1+4577787.37^{*} \exp \left(-0.03^{*} t\right)\right)$ & $0.03^{*}$ \\
\hline AG 9045 & $y=11088.96 /\left(1+4618096.19^{*} \exp \left(-0.04^{*} t\right)\right)$ & 0.30 \\
\hline $\mathrm{P} 1630 \mathrm{H}$ & $y=111577.34 /(1+4558048.7 * \exp (-0.01 * t))$ & 0.25 \\
\hline AG 8025 & $y=0.02 /(1+37.21 * \exp (-0.1 * t))$ & $0.04^{*}$ \\
\hline \multicolumn{3}{|c|}{ Northern corn leaf blight } \\
\hline Hybrids & Equation & p \\
\hline $\mathrm{P} 1630 \mathrm{H}$ & $y=-36612 /\left(1-7061548^{*} \exp \left(-0.05^{\star} t\right)\right)$ & 0.05 \\
\hline $2 A 106$ & $y=4956468.1 /\left(1+470799237.89^{*} \exp (-0.04 * t)\right)$ & 0.05 \\
\hline SW394TL & $y=0.29 /\left(1+4194.24^{*} \exp \left(-0.05^{\star} t\right)\right)$ & $0.01^{*}$ \\
\hline AG 8025 & $y=3015.81 /\left(1+595417.98^{*} \exp \left(-0.03^{*} t\right)\right)$ & $0.01 *$ \\
\hline SYN7205 & $y=0.57 /\left(1+158.46^{*} \exp \left(-0.04^{*} t\right)\right)$ & $0.006^{*}$ \\
\hline P2530 & $y=0.20 /\left(1+19.14^{*} \exp \left(-0.04^{*} t\right)\right)$ & $0.03^{*}$ \\
\hline 2B587 & $y=534.99 /(1+165347.09 * \exp (-0.04 * t))$ & $0.01^{*}$ \\
\hline $30 F 53$ & $y=0.62 /\left(1+94.02^{*} \exp \left(-0.02^{*} t\right)\right)$ & 0.18 \\
\hline AG 9045 & $y=-37055.7 /\left(1-6873894^{*} \exp \left(-0.03^{*} t\right)\right)$ & 0.09 \\
\hline $2 A 550$ & $y=-18764.14 /\left(1+17046356.36^{*} \exp \left(-0.05^{*} t\right)\right)$ & $0.009 *$ \\
\hline
\end{tabular}

*significant $p<0.05$. 


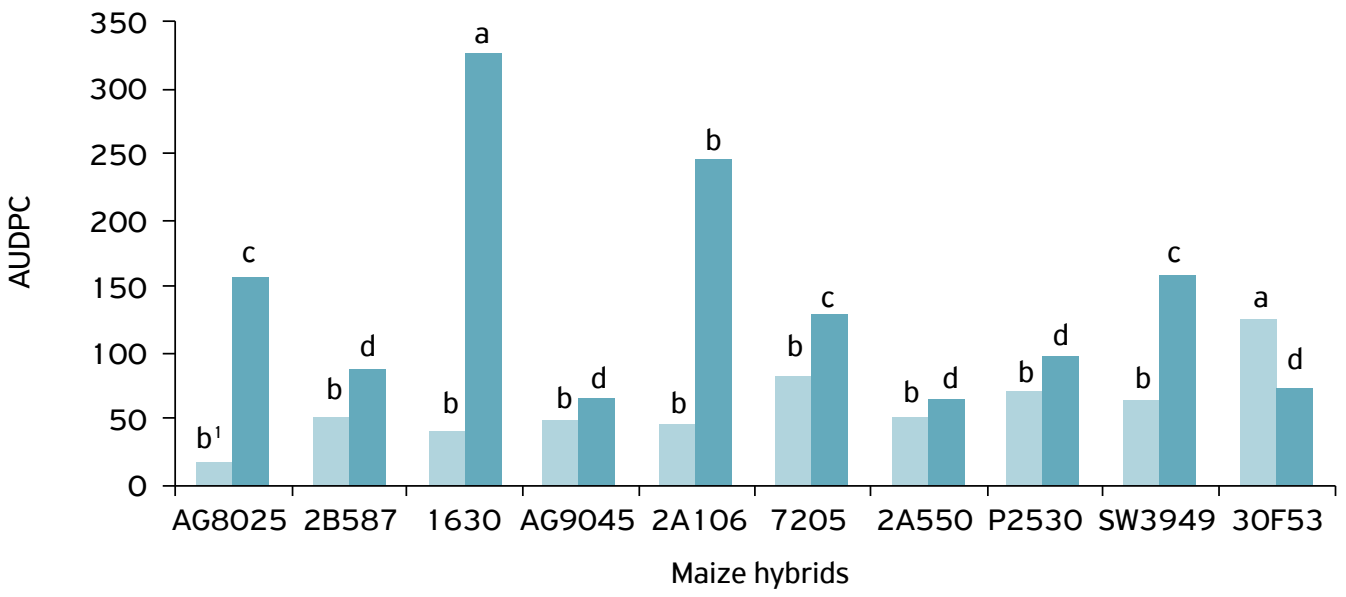

Common rust $\quad$ Northern corn leaf blight (NCLB)
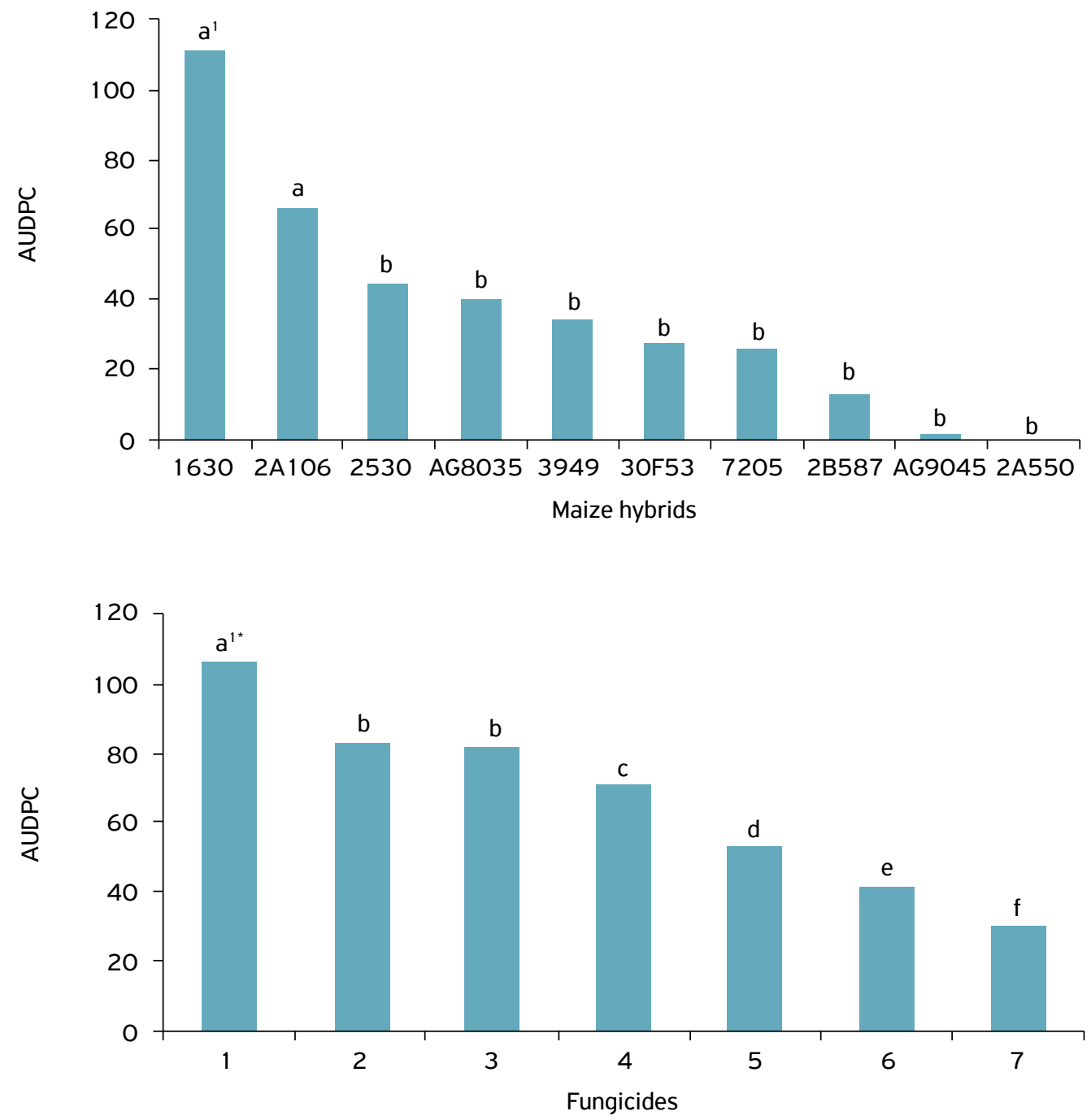

'Means followed by the same letter do not differ by the Scott-Knott test at $5 \%$ of probability.

* 1: control; 2: cyproconazol + azoxystrobin; 3: azoxystrobin; 4: benzovindiflupyr + azoxystrobin; 5: propiconazole; 6: ciproconazole + azoxystrobin + mancozeb; 7 : prothioconazol + trifloxystrobin.

Figure 3. (A) Area under the common rust and Northern corn leaf blight progress curve in maize in the 2012/13 crop. (B) Area under the Northern corn leaf blight severity progress curve of corn. $(C)$ Area under the common rust and Northern corn leaf blight severity progress curve 2013/14 crop. Passo Fundo, Rio Grande do Sul, 2015. 
disease progression. A greater correlation between the level of horizontal resistance and the incubation period is observed (CARSON, 2006).

\section{Experiment 2: Exserohilum turcicum chemical control}

The fungicides prothioconazole + trifloxystrobin, cyproconazole + azoxystrobin + mancozeb and propiconazole showed the lowest values of helmintosporiosis severity, displaying the highest control values of 60,54 and $48 \%$ respectively. When application times were compared, the fungicides propiconazole, cyproconazole + azoxystrobin + mancozeb and prothioconazole + trifloxystrobin applied at the pre-tasseling stage were superior to the application of cyproconazole + azoxystrobin applied in LDE, azoxystrobin, cyproconazole + azoxystrobin and benzovindiflupir + azoxystrobin applied in pre-tasseling (Table 4).

For the AUDPC of NCLB, it was verified that the lowest value was found in the fungicide prothioconazole + trifloxystrobin, which was statistically superior to all the treatments. The highest AUDPC values were found in the fungicides cyproconazole + azoxystrobin and azoxystrobin. All fungicide treatments were statistically superior to the control (Fig. 3C).

Regarding the yield and weight of one thousand seeds, no difference was found between treatments. According to COSTA; COTA (2009), this protection is conferred during part of the grain filling period, which is the most important stage of the crop cycle.

VILELA et al. (2012) showed that the application of the fungicides pyraclostrobin + epoxiconazole and azoxystrobin + ciproconazole in maize was efficient in the control of foliar diseases, as evidenced by the lower incidence rates of the diseases. In this experiment, the tested fungicide azoxystrobin + cyproconazole showed high severity, which may be related to the fungi's resistance to this chemical molecule. This has been occurring with several diseases due to the incorrect use of fungicides.

When evaluating E. turcicum, in the sorghum crop, COTA et al. (2010) reported that in genotypes with good NCLB resistance levels, it was observed that the application of fungicide does not contribute to the effective control of the disease because the genotype's resistance level was sufficient

Table 4. Severity of the last evaluation of Northern corn leaf blight and control efficiency resulting from the application of different fungicides, 2013/14 crop. Passo Fundo, Rio Grande do Sul, 2015.

\begin{tabular}{lccc|} 
Treatments & \multicolumn{2}{c}{ Severity (\%) } & Control (\%) \\
\hline Control & 16.15 & $\mathrm{a}^{1}$ & - \\
\hline Azoxystrobin & 12.00 & $\mathrm{a}$ & 25 \\
\hline $\begin{array}{l}\text { Cyproconazole + } \\
\text { azoxystrobin }\end{array}$ & 11.62 & $\mathrm{a}$ & 28 \\
\hline $\begin{array}{l}\text { LDE (cyproconazole + } \\
\text { azoxystrobin) }\end{array}$ & 11.80 & $\mathrm{a}$ & 27 \\
\hline $\begin{array}{l}\text { Benzovindiflupir + } \\
\text { azoxystrobin }\end{array}$ & 10.37 & $\mathrm{a}$ & 36 \\
\hline $\begin{array}{l}\text { Propiconazole } \\
\text { Cyproconazole + }\end{array}$ & 8.42 & $\mathrm{~b}$ & 48 \\
\hline $\begin{array}{l}\text { azoxystrobin + mancozeb } \\
\text { Prothioconazole + } \\
\text { trifloxystrobin }\end{array}$ & 7.37 & $\mathrm{~b}$ & 54 \\
\hline \begin{tabular}{l} 
CV (\%) \\
\hline
\end{tabular} & 6.37 & $\mathrm{~b}$ & 60 \\
\hline
\end{tabular}

'Means followed by the same letter do not differ by the Scott-Knott test at $5 \%$ of probability; CV: coefficient of variation.

Table 3. Yield and one thousand seed weight of different corn hybrids in 2012/13 crop and 2013/14 crop. Passo Fundo, Rio Grande do Sul, 2015.

\begin{tabular}{|c|c|c|c|c|c|c|c|c|}
\hline \multirow{3}{*}{$\begin{array}{l}\text { Treatments } \\
\text { AG8025 }\end{array}$} & \multirow{2}{*}{\multicolumn{2}{|c|}{$\begin{array}{l}\text { Yield (kg/ha) } \\
2012 / 13 \text { crop }\end{array}$}} & \multicolumn{2}{|c|}{ WTS (g) } & \multicolumn{2}{|c|}{ Yield (kg/ha) } & \multicolumn{2}{|c|}{ WTS (g) } \\
\hline & & & \multicolumn{2}{|c|}{$2012 / 13$ crop } & \multicolumn{2}{|c|}{$2013 / 14$ crop } & \multicolumn{2}{|c|}{$2013 / 14$ crop } \\
\hline & 9077.23 & $a^{1}$ & 246.44 & $a$ & 8173.15 & $a$ & 300.58 & $\mathrm{a}$ \\
\hline 2B587 & 8190.20 & $a$ & 195.15 & c & 9805.11 & $a$ & 216.97 & $b$ \\
\hline $\mathrm{P} 1630 \mathrm{H}$ & 7996.51 & $a$ & 221.82 & $b$ & 7992.30 & $\mathrm{a}$ & 306.26 & $\mathrm{a}$ \\
\hline AG9045 & 7782.39 & $a$ & 274.16 & $a$ & 8551.35 & $a$ & 320.41 & $\mathrm{a}$ \\
\hline $2 \mathrm{~A} 106$ & 7581.25 & $a$ & 219.33 & $\mathrm{~b}$ & 9798.59 & $a$ & 205.27 & $b$ \\
\hline SYN7205 & 7382.85 & $a$ & 212.66 & $\mathrm{~b}$ & 3433.91 & C & 247.45 & $\mathrm{~b}$ \\
\hline $2 A 550$ & 7335.23 & $\mathrm{a}$ & 245.38 & $a$ & 8240.50 & $\mathrm{a}$ & 254.90 & $b$ \\
\hline P2530 & 7330.07 & $a$ & 248.21 & $a$ & 2803.53 & C & 280.89 & $\mathrm{a}$ \\
\hline SW3949TL & 5848.19 & $\mathrm{~b}$ & 182.76 & $\mathrm{C}$ & 5767.50 & $b$ & 221.13 & $b$ \\
\hline $30 F 53$ & 5838.82 & $\mathrm{~b}$ & 221.65 & $\mathrm{~b}$ & 5770.21 & $b$ & 292.87 & $\mathrm{a}$ \\
\hline CV (\%) & 11.5 & & 7.6 & & 16.8 & & $11 . \varepsilon$ & \\
\hline
\end{tabular}

'Means followed by the same letter in the column do not differ by the Scott-Knott test at $5 \%$ of probability; WTS: weight of one thousand seeds; CV: coefficient of variation. 
to control the disease with no need for fungicide application. The data obtained with the fungicide mancozeb are in agreement with BERGER (1973), as it was efficient in controlling E. turcicum in sweet corn, with no reports of phytotoxic effect in this crop. SHARMA; MISHRA (1988) also reports that E. turcicum infection in maize crops was effectively controlled by six sprays of mancozeb $(0.2 \%)$, at 10 -day intervals, from three days after inoculation at 30 days after sowing. The infection rate was reduced and the grain yield increased in this treatment.

In sorghum culture, COTA et al. (2010) reported that the mixture of fungicides epoxiconazole + pyraclostrobin $(0.75 \mathrm{~L} / \mathrm{ha})$ was efficient in controlling E. turcicum.

Regarding application time, COSTA; COTA (2009) reported that two applications of epoxiconazole + pyraclostrobin $(0.50 \mathrm{~L} / \mathrm{ha})$ (at 50 days after sowing and at tasseling) had similar effects in controlling NCLB to one application at the dose of $(0.75 \mathrm{~L} / \mathrm{ha})$ at tasseling. However, the treatment with two applications of the fungicide (ground spray at 50 days after sowing + aerial spraying at tasseling) was statistically similar to the single application at a dose of $0.50 \mathrm{~L} / \mathrm{ha}$ at 50 days after sowing. These results demonstrate that to control this disease, the later applications were more effective than the early applications.

The data found in this study in relation to the chemical control of NCLB agree with ZANATTA (2013), who tested different fungicides for the control of NCLB in maize, showing that the fungicide trifloxystrobin + prothioconazole presented the smaller area under the disease progress curve. This author also mentions that the pressure of diseases varies greatly from one crop to another and depends mainly on the climatic conditions.

ZANATTA (2013) also reports that when the triazole (Cyproconazole) only treatment and strobilurin (Trifloxystrobin) only treatment were used, no reduction was found in the AUDPC. This result reflects the low reduction capacity of $E$. turcicum using treatments with isolated fungicides. In addition, the best alternative to reduce AUDPC was using mixed treatments. This result agrees with the findings by COTA et al. (2010), who demonstrated that the fungicide mixture was efficient in controlling NCLB in sorghum, representing the best control alternative.

\section{CONCLUSIONS}

The hybrids SYN7205, P2530, SW 3949 TL, 2B587, AG 9045, $2 \mathrm{~A} 550, \mathrm{P} 1630 \mathrm{H}, 2 \mathrm{~A} 106$ and AG 8025 show the smallest areas under the common rust severity progress curve in the 2012/13 harvest.

The hybrids AG9045, 30F53, and 2A550 present the smallest areas under the NCLB progress curve.

The hybrids AG8025, 2B587, P1630H, AG9045, 2A106, 2A550 show the highest yields in the 2012/13 crop.

The fungicides prothioconazole + trifloxystrobin show the highest chemical control efficiency of NCLB and the lowest AUDPC.

\section{ACKNOWLEDGEMENTS}

The authors would like to thank the financial support granted by Research Support Foundation of the State of Rio Grande do Sul (FAPERGS) and Universidade de Passo Fundo. This study was also financed in part by the Coordenaçáo de Aperfeiçoamento de Pessoal de Nível Superior - Brasil (CAPES) - Finance Code 001.

| | | | | | | | | | | | | | | | | | | | | | | | | | | | | | | | | | | | | | | | | | | | | | | | | | | | | | | | | | | | | | | | | | | | | | | | | | | | | | | | | | | | | | | | | | | | | | | | | | | | | | | | | | | | | | | | | | | | | | | | | | | | | | | | | | | | | | | | | | | | | | | | | | | | | | | | | | | | | | | | | | | | | | | | | | | | | | | | | | | | | | | | | | | | | | | | | | | | | | | | | | | | | | | | | | | | | | | | | | | | | REFERENCES

AGROCERES. Guia Agroceres de Sanidade. 2. ed. São Paulo: Sementes Agroceres, 1996. 72p.

BALMER, E.; PEREIRA O.A.P. Doenças do milho. In: PATERNIANI, E.; VIÉGAS, G.P. (Eds.) Melhoramento e produção do milho. 2. ed. Campinas: Fundação Cargill, 1987. p.595-634.

BERGER, R.D. Helminthosporium turcicum lesion numbers related to numbers of trapped spores and fungicide sprays. Phytopathology, St. Paul, v.63, p. 930-933, 1973.

CAMPAÑA, A.; PATAKY, J. K. Frequency of the $\mathrm{Ht} 1$ gene in populations of sweet corn selected for resistance to Exserohilum turcicumrace. Phytopathology, St. Paul, v.95, n.1, p.85-91, 2005. https://doi.org/10.1094/ PHYTO-95-0085
CARSON, M.L. Response of a maize synthetic to selection for components of partial resistance to Exserohilum turcicum. Plant Disease, v.90, n.7, p.910-914, 2006. https://doi.org/10.1094/PD-90-0910

COMPANHIA NACIONAL DE ABASTECIMENTO (CONAB). Acompanhamento da Safra Brasileira de Grãos, Safra 2015/16 - Quinto levantamento, v.3, n.5, 2016.

COSTA, R.V.; COTA, L.V. Controle químico de doenças na cultura do milho: aspectos a serem considerados na tomada de decisão sobre aplicação. Sete Lagoas: Embrapa Milho e Sorgo, 2009. 11 p. (Circular Técnica 125).

COTA, LV.; COSTA, R.V.; SILVA, D.D.; PARREIRA, D.F. Recomendação para o controle químico da helmintosporiose do sorgo (Exserohilum turcicum). Sete Lagoas: Embrapa Milho e Sorgo, 2010.7p. (Circular Técnica 149). 
DUARTE, R.P.; JULIATTI, F.C.; FEITAS, P.T. Eficácia de diferentes fungicidas na cultura do milho. Bioscience Journal, Uberlândia, v.25, n.4, p. $101-111,2009$.

KIMATI, H.; AMORIM, L.; REZENDE, J.A.M.; BERGAMIN FILHO, A.; CAMARGO, L.E.A. Manual de fitopatologia volume 2: Doenças das plantas cultivadas. 4. ed. São Paulo: Editora Agronômica CERES Ltda., 2005. 494p.

LAGO, F.L.; NUNES, J. Avaliação da produtividade de milho em relação à aplicação de fungicidas em diferentes estádios. Cultivando o Saber, Cascavel, v.1, n. 1, p.17-23, 2008.

PEREIRA, A.A.; ZAMBOLIM, L.; CHAVES, G.M. Melhoramento visando a resistência a doenças. Informe Agropecuário, Belo Horizonte, v. 1 1, n.122, p.82-92, 1985.

PINTO, N.F.J.A. Controle químico de doenças foliares em milho. Revista Brasileira de Milho e Sorgo, v.3, n. 1, p.134-138, 2004. http://dx.doi.org/10.18512/1980-6477/rbms.v3n01p\%25p

REIS, M.E.; CASA, T.R.; BRESOLIN, C.A.A. Manual de diagnose e controle de doenças do milho. 2. ed. rev. atual. Lages: Graphel, 2004. 144p.

RIBEIRO DO VALE, F.X.; JESUS JÚNIOR, W.C.; ZAMBOLIM, L. Epidemiologia aplicada ao manejo de doenças de plantas. Belo Horizonte: Editora Perfil, 2004. $531 \mathrm{p}$.

RITCHIE, S.W.; HANWAY, J.J.; BENSON, G.O. How a corn plant develops. Ames: lowa State University of Science and Technology, 1993. 26p. (Special Report, 48).
SHARMA, J.P.; MISHRA, B. Effect of spray schedule of mancozeb on turcicum leaf blight and impact on grain yield in maize. Indian Journal of Plant Protection, New Delhi, v. 16, n.2, p.189-193. 1988.

UNITED STATES DEPARTMENT AGRICULTURE (USDA). Agricultural Projections, 2015. Available from: <https://www.nass.usda. gov/Publications/Ag_Statistics/2015/index.php>. Accessed on: Nov. 122015.

VILELA, R.G.; ARF, O.; KAPPES, C.; KANEKO, F.H.; GITTI, D.C.; FERREIRA, J.P. Agronomic performance of maize hybrids, according to the foliar fungicide application. Bioscience Journal, Uberlândia, v.28, n.1, p.25-33, 2012.

WEBER, A.J. (2010) Controle químico de moléstias foliares em milho (Zea mays L.). 2010. 49p. Trabalho de conclusão de curso. UNIJUÍ - Universidade regional do noroeste do estado do Rio Grande do Sul, ljuí, 2010. Available from: http://bibliodigital.unijui.edu.br:8080/ xmlui/bitstream/handle/123456789/648/Adriano\%20 -\%20TCC\%20I1\%20Formatado\%20Por\%20Michel\%20 Net.Copy.pdf?sequence $=1$. Accessed on: Nov. 162015 .

ZANATTA, P. (2013) Controle preventivo de doenças foliares em híbridos comerciais de milho com fungicidas em espaçamento reduzido. 2013. 100p. Dissertação de Mestrado - Universidade Estadual do Centro-Oeste, cidade, 2013. Available from: http://www.unicentroagronomia.com/ imagens/noticias/dissertacao_final_priscila_zanatta.pdf.. Accessed on: Nov. 162015. 